\title{
EXPERIMENTAL STUDY OF A DOMESTIC SOLAR HEATER WITH IRON ORE AS THE ABSORBER
}

\begin{abstract}
D. L. F. Pottie ${ }^{a}$,
L. H. C. Dias ${ }^{\text {, }}$

R. P. Mendes ${ }^{\mathrm{a}}$,

L. V. S. Martins',

and R. A. M. Ferreira ${ }^{a}$

${ }^{a}$ Universidade Federal de Minas Gerais

Programa de Pós-graduação em Engenharia

Mecânica

Av. Antônio Carlos, 6627

CEP. 31270-901, Belo Horizonte, Minas

Gerais, Brasil

dpottie@gmail.com

\section{ABSTRACT}

In Brazil's households, the use of electricity to heat water prevails, but its replacement by solar collectors can be justified due to the country's high level of solar radiation, average temperature and number of sunny days. A drawback preventing the broad spread of this technology its elevated inicial cost that, in spite of the short return on investment time, hinders its insertions on the population lower classes. Thereby, this study's goal is to search a cheaper alternative to one of the collector's most expensive component, by proposing the replacement of the aluminium sheets, used as absorber, by iron ore. This material was chosen due to its abundance in Minas Gerais, low cost and for being dark colored, ensuring high levels of absortance $(0,4<\lambda<0,7 \mu \mathrm{m})$. A finely grained hematitic $\left(\mathrm{Fe}_{2} \mathrm{O}_{3}\right)$ ore was used to achieve an uniform compaction throughout its area, reducing this way, the thermal contact resistance between the absorber and the copper tubes. The collector was built and tested in similar conditions it would have faced during its lifespan, and the result shows that the maximum thermal efficiency was $58 \%$.
\end{abstract}

ramondepaoli@yahoo.com.br

r.ferreira102@hotmail.com

${ }^{\mathrm{b}}$ Universidade Federal de Minas Gerais

Laboratório de Termometria

Av. Antônio Carlos, 6627

CEP. 31270-901

Belo Horizonte, Minas Gerais, Brasil

leonardohcdias@gmail.com

'Universidade Federal de Minas Gerais

Grupo de Refrigeração e Aquecimento

Av. Antônio Carlos, 6627

CEP. 31270-901

Belo Horizonte, Minas Gerais, Brasil

leo.vsm@hotmail.com
Keywords: flat plate collectors; iron ore; water heating

Received: January 20, 2020

Revised: February 23, 2020

Accepted: May 24, 2020

\section{NOMENCLATURE}

k Thermal conductivity, $\mathrm{Wm}^{-1} \mathrm{~K}^{-1}$

$c_{p} \quad$ specific heat, $\mathrm{J} \mathrm{kg}^{-1} \mathrm{~K}^{-1}$

$G_{\mathrm{T}} \quad$ incident radiant energy, $\mathrm{W}$

$\dot{m} \quad$ mass flow rate, $\mathrm{kg} \mathrm{s}^{-1}$

$Q_{\mathrm{U}} \quad$ useful heat, W

$\mathrm{T} \quad$ Temperature, ${ }^{\circ} \mathrm{C}$

\section{Greek symbols}

$\alpha \quad$ absorption coefficient

$\rho$ reflectivity

$\eta \quad$ thermal efficiency

\section{Subscripts}

1 inlet

$$
\begin{array}{ll}
2 & \text { outlet } \\
4 & \text { ambient }
\end{array}
$$

\section{INTRODUCTION}

In the domestic sphere, obtaining hot water using electric resistors is predominant - Naspolini and Rüther (2011) indicate that $73 \%$ of homes have electric showers or use electricity for this purpose which represents a considerable portion of the expenses of a family with electricity. It is not uncommon to find showers with powers in the order of $5.5 \mathrm{~kW}$ installed in the residences of the most diverse social classes and in all regions of the country. An alternative to this technology, whose representativeness is increasing not only in Brazil as in the rest of the world, is the use of solar collectors that transform radiant energy from the sun into sensible heat Thirugnanasambandam et al. (2010). 
This work proposes to suggest the use of finelygrained iron ore instead of calendered and painted aluminum sheets, which may present itself as a cheaper and more affordable alternative. Although the ore is a ceramic material, thus having a relatively low thermal conductivity $k$, around $12 \mathrm{Wm}^{-1} \mathrm{~K}^{-1}$ (Clauser and Huenges, 1995), it has a very dark and opaque coloration, which could represent an interesting property in terms of absorptivity in the solar spectrum. In this way, this work experimentally obtained values for the thermal efficiency of a collector constructed in a similar way as the conventional one Fig. 1(a) in several operational regimes.

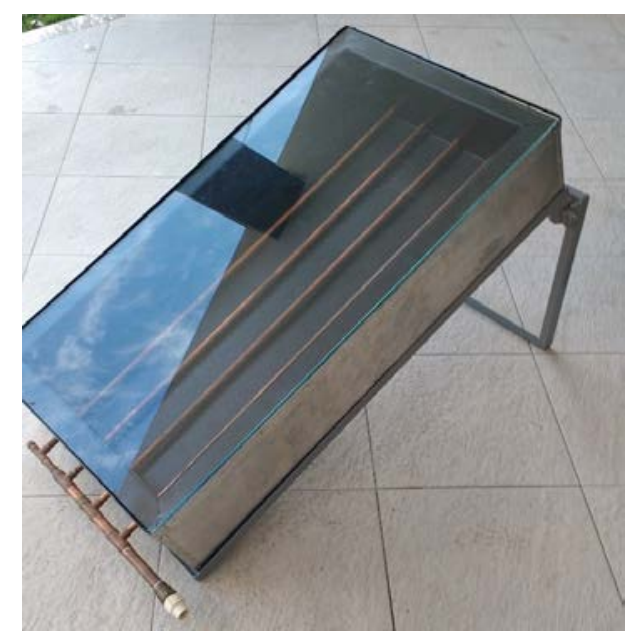

(a)

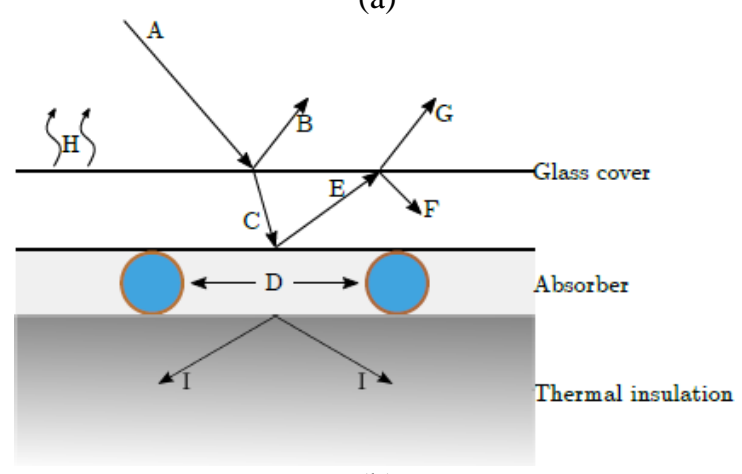

(b)

Figure 1. (a) Constructed prototype and (b) Thermal phenomena associated to heat flows in a sollar collector.

In Brazil, the use of electric showers in the domestic sphere, regardless of social class or the region of the country, is the majority. According to Naspolini and Rüther, 2011, the use of methods dependent on the direct use of electric energy in water heating represents $73.1 \%$ of the total, and corresponds to approximately $22 \%$ of the monthly electricity bill of a household (Eletrobrás/PROCEL, 2007); Achão and Schaeffer, 2004).

In terms of collectors, Kalogirou (2004) defines a solar collector as a heat exchanger that captures radiant energy and transfers it, as sensitive heat, to the fluid of interest. For households, flat plate solar collectors are the most widespread because they have a simple construction, low maintenance and long lifetime. They are generally installed on the roofs of the houses, with a fixed slope and facing north towards the equator, in order to maximize the energy absorption throughout the day (Kalogirou, 2004).

The thermal phenomena associated to the operation of a flat plate solar collector is shown in Fig. 1(b): In that the incident radiation $(A)$ reaches the glass surface, being part reflective $(B)$ and part transmitted $(C)$. The latter $(C)$ reaches the absorptive surface, which must have high absorptivity indexes, so that the portion of reflected energy $(E)$ is much lower than that absorbed and transmitted to the water $(D)$. The fraction reflected in the absorber again reaches the glass, part being reflected back into the collector $(F)$ and part transmitted to the environment $(G)$. The thermal losses of the collector can be divided into convective losses by the glass $(H)$ and conductive by the thermal insulation $(I)$.

In a solar collector the absorber surface aims to absorb the maximum possible incident radiation, and transmit it efficiently to the tubes and consequently to the water, heating it. Thus, an ideal material for this purpose must have high absorption coefficients $(\alpha)$ and coefficients of thermal conductivity $(k)$, while it must have low reflectivity $(\rho)$. Consequently, it is common to use painted metal in black and in conventional collectors, it is used of an aluminum plate, thickness of $1 \mathrm{~mm}$, coated with dark paint and resistant to sunlight.

In order to replace the aluminum with an alternative material for the absorber, of lower cost, the present work suggested the use of iron ore. In this way, the methodology used and the results obtained will be presented below.

\section{METHODOLOGY}

As the proposed collector aims to analyze the effect of the substitution of aluminum used on standard absorbers by iron ore, it was constructed in a similar way to commercial flat plate solar collectors, so that the consequences of this change could be easily observed. The main dimensions were initially defined Fig. 2(a) and the materials used in each of the collector components Tab. 1.

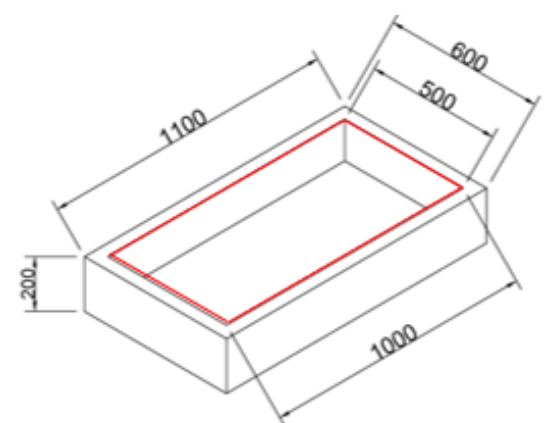

(a) 


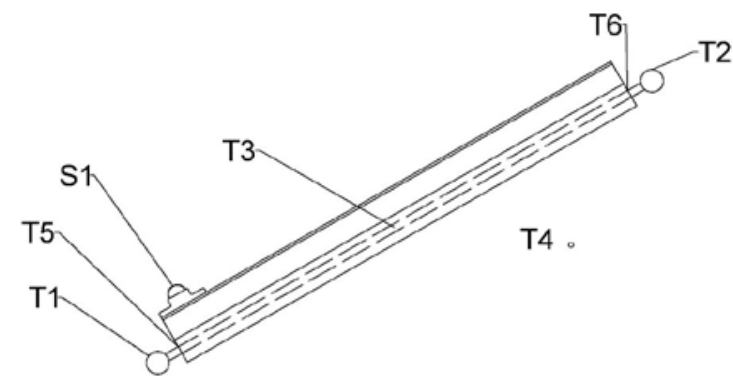

(b)

Figure 2. Arrangement of finned elliptic tubes, and the three dimensional computational domain.

Table 1. Material used in the construction.

\begin{tabular}{|c|c|c|}
\hline Components & Material used & Characteristic \\
\hline Cover & Glass & $\begin{array}{c}\text { Thickness 3 } \\
\mathrm{mm}\end{array}$ \\
\hline Tubes & Copper & $\begin{array}{c}\text { Diameters } 15 \\
\mathrm{~mm} \text { and } 22 \mathrm{~mm}\end{array}$ \\
\hline $\begin{array}{c}\text { Internal and } \\
\text { external boxes }\end{array}$ & Aluminium & $\begin{array}{c}\text { Thickness } 1 \\
\mathrm{~mm}\end{array}$ \\
\hline $\begin{array}{c}\text { Thermal } \\
\text { insulation }\end{array}$ & Rockwool & $\begin{array}{c}\text { Density } 64 \\
\text { kg/m }{ }^{-3} 3 \text { and } \\
\text { thickness } 50 \\
\mathrm{~mm}\end{array}$ \\
\hline Absorber & Hematite & $\begin{array}{c}\text { Fine grains and } \\
\text { high purity }\end{array}$ \\
\hline
\end{tabular}

For the acquisition of the data of interest during the tests, a set of six thermocouples (to $T_{1} T_{6}$ ) and one pyranometer $\left(S_{1}\right)$ installed in the assembly were used as shown in Fig. 2(b).

\section{Experimental procedure}

The tests were performed from August $28^{\text {th }}$ to $30^{\text {th }}$, 2016, in Belo Horizonte, at coordinates $19.967754{ }^{\circ} \mathrm{S}$ and $43.9476{ }^{\circ} \mathrm{W}$, taking place from 10:00 a.m. to 2:00 p.m. The test procedure was standardized to ensure that the effects resulting from the variation of parameters that could not be measured were considerably less than the influence of the measurements measured by the instruments.

Firstly, it was determined whether the atmospheric conditions (wind and cloudiness) were adequate for carrying out the test. Then, using the flow diverter built into the reservoir inlet, the flow rate of the system was adjusted. The literature (Duffie and Beckman, 1991) indicates that values usual for solar collector assays are around $1.2 \mathrm{\ell} \mathrm{m}^{-2} \mathrm{~min}^{-1}$. Since the collector area was constructed at $0.5 \mathrm{~m}^{2}$, the voltage applied to the pump and the valve opening were adjusted to obtain a flow rate of about $0.6 \mathrm{l} \mathrm{m^{-2 }}$ $\mathrm{min}^{-1}$. For this purpose, a graduated glass reservoir and a stopwatch were used. The next step was to record the start date and time of the trials. The test was initiated by the software interface of the data acquisition system. It was set up for measurements with frequency of $1 \mathrm{~Hz}$, and each test lasted for 5 minutes, which represents a total of 300 measurements obtained by the instruments. After 5 minutes, the data acquisition system interrupted the test, and the results were presented in Excel spreadsheet format. Finally, an interval of 15 to 20 minutes between two tests was expected so that variations due to atmospheric changes could manifest themselves in the system. At the end, 10 tests were performed.

\section{Mathematical equations}

In order to evaluate the behavior and performance of the solar collector, it was necessary that the obtained values be manipulated in order to obtain performance graphs and the calculation of the thermal efficiency. The following calculations will be presented:

$$
Q_{U}=\dot{m} \cdot c_{p} \cdot\left(\mathrm{T}_{2}-\mathrm{T}_{1}\right)
$$

The useful heat $Q_{U}$ is defined as the thermal energy that has in fact been transformed into sensible heat for the water, and can be determined according to Eq. (1), using measured quantities and obtained in the literature. In which $Q_{U}$ is the useful heat (W), $\dot{m}$ is the mass flow rate $\left(\mathrm{kg} \mathrm{s}^{-1}\right), c_{p}$ is the specific heat of water equal to $4180\left(\mathrm{~J} \mathrm{~kg}^{-1} \mathrm{~K}^{-1}\right)$ and $T_{1}$ and $T_{2}$ are the temperatures at the inlet and outlet, respectively $\left({ }^{\circ} \mathrm{C}\right)$.

$$
\eta=\frac{Q_{U}}{G_{T}}
$$

The thermal efficiency $\eta$ is characterized as the energy ratio useful by the incident energy, analyzed in the same period of time (Duffie and Beckman, 1991), and can be calculated using Eq. (2) where $\eta$ is the thermal efficiency (\%), $Q_{\mathrm{U}}$ is the useful heat (W) and $G_{\mathrm{T}}$ is the incident radiant energy (W) measured by the pyranometer.

$$
F=\frac{\mathrm{T}_{1}-\mathrm{T}_{4}}{G_{T}}
$$

Finally, it is usual in solar collector analysis to define a temperature and radiation factor, which is defined as the ratio of the fluid input temperature difference $\left(T_{1}\right)$ and the ambient $\left(T_{4}\right)$ by the incident radiant energy ( $G_{\mathrm{T}}$ ) as presented in Eq. (3). 
Table 2. Overview of the results in each test. The first eight columns are the average of each instruments over each test. The last tree columns are resulted from the mathematical equations hereby described.

\begin{tabular}{|c|c|c|c|c|c|c|c|c|c|c|c|}
\hline Test & $T_{1}$ & $T_{2}$ & $T_{3}$ & $T_{4}$ & $T_{5}$ & $T_{6}$ & $S_{1}$ & $\dot{m}$ & $Q_{u}$ & $\eta$ & $\mathrm{F}$ \\
\hline$\#$ & \multicolumn{9}{|c|}{${ }^{\circ} \mathrm{C}$} \\
\hline 1 & 34.5 & 41.8 & 67.4 & 33.9 & 39.5 & 58.4 & 899.6 & 0.0095 & 285.3 & 63.4 & 0.001 \\
\hline 2 & 35.6 & 39.7 & 58.2 & 28.9 & 42.0 & 53.7 & 883.9 & 0.0093 & 189.0 & 42.8 & 0.008 \\
\hline 3 & 42.2 & 46.4 & 65.6 & 31.3 & 46.9 & 60.0 & 928.9 & 0.0110 & 158.2 & 34.1 & 0.012 \\
\hline 4 & 43.0 & 48.3 & 67.9 & 32.0 & 47.9 & 61.0 & 326.6 & 0.0091 & 241.9 & 52.2 & 0.012 \\
\hline 5 & 29.9 & 36.2 & 69.6 & 31.3 & 36.0 & 53.7 & 879.9 & 0.0110 & 290.1 & 61.9 & -0.002 \\
\hline 6 & 37.5 & 41.9 & 68.4 & 31.7 & 42.7 & 57.5 & 879.9 & 0.0110 & 235.8 & 53.6 & 0.007 \\
\hline 7 & 40.5 & 44.1 & 65.6 & 33.1 & 44.9 & 59.5 & 911.4 & 0.0130 & 150.5 & 33.0 & 0.008 \\
\hline 8 & 42.4 & 45.9 & 68.9 & 34.8 & 44.2 & 60.6 & 1014.8 & 0.0100 & 160.5 & 31.6 & 0.008 \\
\hline 9 & 35.8 & 41.0 & 54.0 & 32.9 & 41.3 & 51.0 & 817.0 & 0.0092 & 199.2 & 48.8 & 0.003 \\
\hline 10 & 37.8 & 42.5 & 56.6 & 30.5 & 43.2 & 53.2 & 847.5 & 0.0095 & 185.4 & 43.8 & 0.009 \\
\hline
\end{tabular}

\section{RESULTS AND DISCUSSION}

The results will be divided into measured and calculated quantities. Firstly, the averages of the measured quantities are presented in Tab. 2. It can be observed in the Tab.2 that the levels of incident solar radiation reached high values, close to $900 \mathrm{Wm}^{-2}$, thus indicating that the climate was conducive to the tests. The temperatures obtained in the tests indicate that the heater has fulfilled its function of heating the water. The thermocouple ( $\left.T_{3}\right)$ was installed inside the ore layer, and from Tab. 2, it is noted that high temperatures were reached. This indicates that despite the high absorptivity levels, the low thermal conductivity $k$ hinders the diffusion and delivery of thermal energy to the fluid.

Then, in the last three columns of Tab. 2, the quantities calculated from the equation described in the previous item are presented.

Note that the higher values of thermal efficiency were obtained under the conditions where the radiation factor and temperatures $F$ is lower, a behavior expected and predicted by Duffie and Beckman (1991). This is due to two independent facts, which may occur simultaneously: (i) the maximum temperature difference of the fluid at the entrance to the environment or (ii) larger incident solar radiation rates lead to a greater heat transfer and, consequently, higher transmission of energy to water.

\section{REFERENCES}

Achão, C. C. L., and Schaeffer, R., 2004, Energia e Classes de Renda no Brasil: um Retrato do Consumo no Setor Residencial, in: Anais do $X$ Congresso Brasileiro de Energia: A Universalização do Acesso à Energia. UFRJ, COPPE, Vol. 4, pp. 2403-2417. (in Portuguese)

Clauser, C., and Huenges, E., 1995, Thermal Conductivity of Rocks and Minerals, American Geophysical Union, pp. 105-126.

Duffie, J. A., and Beckman, W. A., 1991, Solar
Engineering of Thermal, Wiley New York, 2nd Edition.

Eletrobrás/PROCEL, 2007, Avaliação do Mercado de Eficiência Energética no Brasil: Pesquisa de Posse de Equipamentos e Hábitos de Uso, Technical Report, Eletrobrás. (in Portuguese)

Kalogirou, S. A., 2004, Solar Thermal Collectors and Applications, Progress in Energy and Combustion Science, Vol. 30, No. 3, pp. 2310295.

Naspolini, H. F., and Rüther, R., 2011, The Impacts of Solar Water Heating in Low-Income Households on the Distribution Utility's Active, Reactive and Apparent Power Demands, Solar Energy, Vol. 85, No. 9, pp. 2023-2032.

Thirugnanasambandam, M., Iniyan, S., and Goic, R., 2010, A Review of Solar Thermal Technologies, Renewable and Sustainable Energy Reviews, Vol. 14, No. 1, pp. 312-322. 